\title{
Aphid species (Hemiptera: Aphididae) new in the fauna of the Eastern Beskid Mountains (southern Poland)
}

\author{
Natalia KASZYCA, Miłosz MORAWSKI, Artur TASZAKOWSKI and Łukasz DEPA \\ Department of Zoology, Faculty of Biology and Environmental Protection, University of Silesia, Bankowa 9, 40-007 \\ Katowice,Poland; nkaszyca@us.edu.pl,mmorawski1@us.edu.pl, artur.taszakowski@us.edu.pl, \\ lukasz.depa@us.edu.pl (corresponding author)
}

\begin{abstract}
Fifteen aphid species were found in the Eastern Beskid Mountains for the first time during the short faunistic study. Currently, 119 aphid species are recorded from this region, which may still constitute only a fraction of the fauna of neighboring regions and testify to an insufficient faunistic study on aphids.
\end{abstract}

Key words: faunistics, new records, aphids, zoogeography, Poland

\section{INTRODUCTION}

Aphididae belong to the order Hemiptera, suborder Sternorrhyncha, which apart from aphids includes various insect groups that are sap-sucking phytophages (Osiadacz \& Hałaj 2009). Aphids, contrary to most of other insects, are a group reaching its highest species diversity in the zone of moderate climates. Poland is among the best studied European countries in terms of aphid fauna, with 766 recorded aphid taxa (Wojciechowski et al. 2015, Kanturski et al. 2017). However, particular regions of Poland are still unevenly studied (Osiadacz \& Hałaj 2009). The region of the Eastern Beskid Mountains still is far from being satisfactorily investigated, despite intensive research of Hemiptera in the last decade (e.g. Taszakowski 2012, Taszakowski et al. 2015b, Taszakowski \& Gorczyca 2018) aphids were not included in these investigations. So far, only 104 aphid species have been known from this area (Osiadacz \& Hałaj 2009, Depa \& Mróz 2013, Depa et al. 2017, Kanturski et al. 2017), of which 96 were not confirmed by any studies since the Catalogue was issued (Szelegiewicz 1968). This is very low number taking into account the large area and high habitat diversity of the Eastern Beskid Mountains. The presence of arable fields, natural forests (Magurski National Park) and farmlands and the proximity of the low trans-Carpathian passes (as a potential pathway for migration of thermophilous species) (Taszakowski \& Gorczyca 2018) can have a major impact on the formation of aphid fauna in this area. The low intensity of aphidological research in this area contributed to the low number of species found so far in this region (Osiadacz \& Hałaj 2009). This paper presents the results of the research project conducted in 2013 in the Eastern Beskid Mountains by members of the Student's Scientific Association "Faunatycy" aiming at complement faunistic data concerning aphid species of this area of Poland.

\section{STUDY AREA AND METHODS}

The studies were conducted from 9 to 12 July 2013 in the small town of Bartne (community: Sękowa, county: Gorlicki). In terms of physical-geographical division of Poland this locality is situated in the mesoregion of the Low Beskids (Kondracki 2013) and the zoogeographical region of the Eastern Beskid Mountains (Burakowski et al. 1973). Many 
orchards with the fruit trees of this village over time have lost their anthropogenic character, thus creating a perfect place for the development of aphids.

Aphids were collected by method of detailed searching of whole plants. A few samples were collected using entomological net. The total number of 35 aphid samples from 15 plant genera was collected. The specimens were preserved in a $70 \%$ ethanol solution. After mounting on microscopic slide with method described by Kanturski \& Wieczorek (2012) the specimens were identified using keys by Blackman \& Eastop (1994, 2006, 2017), Wojciechowski (2003), Wojciechowski et al. (2016) and Heie (1980, 1982, 1986, 1992, 1994, 1995). Systematic order was applied according to Remaudière \& Remaudière 1997. The collected material is deposited in the entomological collection of the Department of Zoology, University of Silesia in Katowice.

\section{RESULTS}

Twenty two aphid species have been recorded in the present study (Table 1). Among the collected species, 15 are recorded in the Eastern Beskid Mountains for the first time. The presence of 7 other recorded species is confirmed for the first time in this region in over fifty years (Szelegiewicz 1968).

Table 1. The list of aphids found in the Eastern Beskids during the study; the species recorded for the first time in the region are marked with an asterisk (*), two asterisks $\left(^{* *}\right)$ mark the first confirmation after 1968.

\begin{tabular}{|c|c|c|c|}
\hline No. & Aphididae & Plant & Date / Remarks \\
\hline \multicolumn{4}{|c|}{ Aphidinae } \\
\hline \multicolumn{4}{|c|}{ Aphidini } \\
\hline 1. & Aphis acetosae Linnaeus, 1761 * & Rumex sp. & $11 \mathrm{Jul} 2013$ \\
\hline 2. & Aphis confusa Walker, 1849 * & Knautia sp. & $09 \mathrm{Jul} 2013$ \\
\hline 3. & Aphis craccae Linnaeus, 1758 * & Vicia sp. & $10 \mathrm{Jul} 2013$ \\
\hline 4. & Aphis farinosa Gmelin, 1790 ** & Salix caprea & 11 Jul 2013 \\
\hline 5. & \multicolumn{2}{|l|}{ Macrosiphini } & 12 Jul 2013 \\
\hline 6. & Dysaphis newskyi aizenbergi (Shaposhnikov, 1949) * & Heracleum sp. & 12 Jul 2013 \\
\hline 7. & Macrosiphum funestum (Macchiati, 1885) * & Rubus caesius & 10 Jul 2013 \\
\hline 8. & \multicolumn{2}{|l|}{ Sitobion avenae (Fabricius, 1775) * } & $\begin{array}{l}09 \mathrm{Jul} 2013 \text { / pasture, cought } \\
\text { in the entomological net }\end{array}$ \\
\hline 9. & Uroleucon aeneum (Hille Ris Lambers, 1939) * & Centaurea jacea & $12 \mathrm{Jul} 2013$ \\
\hline 10. & Uroleucon hypochoeridis (Fabricius, 1779)** & Hieracium sp. & 09 Jul 2013 \\
\hline 11. & \multicolumn{2}{|l|}{ Uroleucon leontodontis (Hille Ris Lambers, 1939) * } & $\begin{array}{l}09 \mathrm{Jul} 2013 \text { / pasture, cought } \\
\text { in the entomological net }\end{array}$ \\
\hline \multirow[t]{2}{*}{12.} & $\begin{array}{l}\text { Uroleucon murale (Buckton, 1876) ** } \\
\text { Lachninae }\end{array}$ & Mycelis muralis & 10 Jul 2013 \\
\hline & \multicolumn{3}{|l|}{ Eulachnini } \\
\hline 13. & Cinara cuneomaculata (Del Guercio, 1909) * & Larix decidua & 10 Jul 2013 \\
\hline 14. & Cinara laricis (Hartig, 1839) * & Larix decidua & $10 \mathrm{Jul} 2013$ \\
\hline 15. & $\begin{array}{l}\text { Cinara pini (Linnaeus, 1758) ** } \\
\text { Lachnini }\end{array}$ & Pinus sylvestris & 09 Jul 2013 \\
\hline \multirow[t]{2}{*}{16.} & Trama troglodytes (Koch, 1857) * & $\begin{array}{l}\text { roots of Artemisia } \\
\text { vulgaris }\end{array}$ & 09 Jul 2013 \\
\hline & \multicolumn{3}{|l|}{ Calaphidinae } \\
\hline 17. & Euceraphis punctipennis (Zetterstedt 1828) * & & $\begin{array}{l}09 \text { Jul } 2013 \text { / cought in the } \\
\text { entomological net }\end{array}$ \\
\hline 18. & Monaphis antennata (Kaltenbach, 1843) ** & & $\begin{array}{l}09 \text { Jul } 2013 \text { / cought in the } \\
\text { entomological net }\end{array}$ \\
\hline 19. & Myzocallis coryli (Goeze, 1778)* & Corylus avellana & 09 Jul 2013 \\
\hline 20. & Symydobius oblongus (Heyden C.H.G., 1837) ** & Betula pendula & $09 \mathrm{Jul} 2013$ \\
\hline
\end{tabular}

Table 1 continued on the next page 
Continuation of the Table 1

\begin{tabular}{llll}
\hline No. & \multicolumn{1}{c}{ Aphididae } & Plant & Date / Remarks \\
\hline 21. & $\begin{array}{l}\text { Phyllaphidinae } \\
\text { Thelaxina fagi (Linnaeus, } 1767)^{*}\end{array}$ & Mycelis sp. $\left({ }^{1}\right)$ & 10 Jul 2013 / \\
22. & Glyphina betulae (Linnaeus, 1758)* & Betula sp. & 09 Jul 2013 \\
\hline
\end{tabular}

$\left({ }^{1}\right)$ - The collection of Phyllaphis fagi on Mycelis sp. concerns a late female, therefore it is only a random collection and no new host plant associations were recorded.

\section{DISCUSSION}

Currently, the total number of aphid species recorded in this area is 119 . This is very low number comparing to other zoogeographical regions of Poland. For example neighboring regions of Sandomierz Lowland, Bieszczady Mountains or Western Beskidy Mountains score ca. 200-250 species of aphids (Osiadacz \& Hałaj 2009). This data illustrates how neglected is the region of the Eastern Beskid Mountains in terms of faunistic research on aphids. Recent considerations of the potential migration routes of thermophilous hemipterans through transCarpathian montane passages (e.g. Taszakowski 2012, Taszakowski et al. 2015a, Taszakowski \& Gorczyca 2018) indicate the importance of this area in development of Polish fauna, including aphids (Kanturski et al. 2017). Further studies should definitely reveal much higher number of aphid taxa in this region. Our cautious estimation indicate that there are at least 100 more species of aphids in this region. With high variety of habitats, good preservation of natural ones, relatively low human activity and longitudinal montane passages the area of the Eastern Beskid Mountains (especially the Low Beskid Mts.) should become the most intensively studied regions in the coming years by us.

\section{REFERENCES}

BLACKMAN R. L. \& EASTOP V. F. 1994. Aphids on the World's Trees. CAB International, Wallingford UK, 987 pp.

BLACKMAN R. L. \& EASTOP V. F. 2006. Aphids on the World's Herbaceous Plants and Shrubs. The Natural History Museum/John Wiley \& Sons, Chichester UK, 1439 pp.

BlackMAn R. L. \& EASTOP V. F. 2017. Aphids on the World's Plants. An online information and information guide. (Available at http://www.aphidsonworldsplants.info (15 Oct 2017).

BurAKowsKi B., MroczKowSKi M. \& STEFAŃSKa J. 1973. Chrząszcze Coleoptera. Biegaczowate - Carabidae. 1. Katalog fauny Polski 23 (2): 1-232.

Depa Ł., Mróz E., Bugaj-Nawrocka A. \& OrCZewska A. 2017. Do ants drive speciation in aphids? A possible case of ant-driven speciation in the aphid genus Stomaphis Walker (Aphidoidea, Lachninae). Zoological Journal of the Linnean Society 179(1): 41-61; DOI: 10.1111/zoj.12437

DEPA Ł. \& Mróz E. 2013. Central European Acer- and Salicaceae-feeding Aphids of the Genus Stomaphis (Insecta: Aphidoidea: Lachnidae) - Separate Species or Populations? Zoological Science 30(6): 509-518.

HeIE O. E. 1980. The Aphidoidea (Hemiptera) of Fennoscandia and Denmark. I. The families Mindaridae, Hormpahididae, Thelaxidae, Anoeciidae and Pemphigidae. Fauna Entomologica Scandinavica 9: 1-236.

HeIE O. E. 1982. The Aphidoidea (Hemiptera) of Fennoscandia and Denmark. II. Family Drepanosiphidae. Fauna Entomologica Scandinavica 11: 1-169.

HEIE O. E. 1986. The Aphidoidea (Hemiptera) of Fennoscandia and Denmark. III. Fauna Entomologica Scandinavica 17: $1-314$.

HEIE O.E. 1992. The Aphidoidea (Hemiptera) of Fennoscandia and Denmark. IV. Fauna Entomologica Scandinavica 25: $1-189$.

HEIE O. E. 1994. The Aphidoidea (Hemiptera) of Fennoscandia and Denmark. V. Family Aphididae: Part 2 of tribe Macrosiphini of subfamily Aphidinae. Fauna Entomologica Scandinavica 28: 1-242.

HEIE O. E. 1995. The Aphidoidea (Hemiptera) of Fennoscandia and Denmark. VI. Fauna Entomologica Scandinavica 31: 1-217.

KANTURSKi M., MrUK K., MorawsKi M., WoJCIECHOWSKi W. \& DePa Ł. 2017. Nearctaphis bakeri (Cowen, 1895) and Illinoia liriodendri (Monell, 1879) - two aphid species (Hemiptera: Aphididae) of alien origin new to the Polish fauna. Annals of the Upper Silesian Museum in Bytom, Entomology 26 (online 002): 1-6.

KANTURSKI M. \& WIECZOREK K. 2012. Metody zbioru i preparowania mszyc (Hemiptera, Aphidoidea) w badaniach faunistycznych, taksonomicznych i molekularnych. Młodzi Naukowcy dla polskiej Nauki 8(5): 137-143. 
KONDRACKI J. 2013. Geografia regionalna Polski. Wydawnictwo Naukowe PWN. Warszawa: 444 pp.

Osiadacz B. \& Halaj R. 2009. The aphids (Hemiptera: Sternorrhyncha: Aphidinea) of Poland. A distributional checklist. Polish Entomological Monographs 6: 1-96.

Remaudiere G. \& Remaudiere M. 1997. Catalogue des Aphididae du Monde. INRA, Paris. 473 pp.

SzELEgIEWICZ H. 1968. Mszyce - Aphidodea. Katalog fauny Polski 21(4): 1-316. PWN, Warszawa.

TASZAKOWSKI A. 2012. Lądowe pluskwiaki różnoskrzydłe (Hemiptera: Heteroptera) doliny górnej Ropy. Acta entomologica silesiana 20: 37-54.

TASZAKOWSKI A. \& GoRCZYCA J. 2018. Pluskwiaki różnoskrzydłe Beskidu Wschodniego - geneza fauny. Monographs of the Upper Silesian Museum in Bytom 8: 1-159.

TASZAKOWSKI A., WALCZAK M. \& BARAN B. 2015a. Reptalus quinquecostatus (Dufour, 1833) (Hemiptera: Fulgoromorpha) - new species of cixiid in Poland. Acta entomologica silesiana 23: 209-216.

TAszakowski A., WalczaK M., Morawski M. \& BARAN B. 2015b. Piewiki (Hemiptera: Fulgoromorpha et Cicadomorpha) Beskidu Wschodniego. Acta entomologica silesiana 23 (online 013): 1-14.

WoJcIEchowsKi W. 2003. A monograph of the Palaearctic Pterocommatinae (Aphididae, Aphidinea, Hemiptera). Prace Naukowe Uniwersytetu Śląskiego w Katowicach 2153: 1-112.

Wojciechowski W., DePa Ł., KANTURSKi M., WĘGIEREK M. \& WiEczoreK K. 2015. An annotated checklist of the aphids (Hemiptera: Aphidomorpha) of Poland. Polish Journal of Entomology 84(4): 383-420.

WojciechowsKi W., DePA Ł.,HALgoŠ J., MATEČNÝ I., LuKÁŠ J. \& KANTURSKI M. 2016. Aphids of Slovakia. Distributional catalogue, checklist, keys and list of host plants. Comenius University in Bratislava Faculty of Natural Sciences, Bratislava, 344 pp.

\section{STRESZCZENIE}

\section{[Mszyce (Hemiptera: Aphididae) nowe w faunie Beskidu Wschodniego (południowa Polska)]}

Podczas krótkich badań faunistycznych w Beskidzie Wschodnim w lipcu 2013 znaleziono 22 gatunki mszyc, z których 15 gatunków okazał o się być stwierdzonymi po raz pierwszy w tym regionie Polski. Do tej pory z Beskidu Wschodniego wykazane były tylko 104 gatunki. W chwili obecnej z tego rejonu znanych jest 119 gatunków mszyc, co według szacunku autorów jest najwyżej połową liczby gatunków stwierdzonych w sąsiednich regionach, świadcząc o bardzo nierównomiernym zbadaniu fauny mszyc na terenie południowej Polski. 